\title{
SOPHIA
}

PEER REVIEW JOURNAL

CROSSING BORDERS, SHIFTING BOUNDARIES - THE AURA OF THE IMAGE

ISSN: 2183-8976 [PRINT] 2183-9468 [ONLINE]

Volume 1, Issue 1| Publication year: 2016

DOI 10.24840/2183-8976_2016-0001_0001_03

(c) SCOPIO EDITIONS

HOMEPAGE: HTTPS:/ /WWW.SOPHIAJOURNAL.NET

\section{EDITORIAL | HOW DO WE THINK THE IMAGE?}

\author{
Written by Susana Ventura
}

We look at an image. It fascinates us. If it truly fascinates us, maybe it holds a mystery or a secret apparently imperceptible. Right at that moment, a paradox is engendered: the photographic or filmic image, belonging to the visual domain, is commonly judged as an object of immediately comprehension, and, yet, towards the image that disconcerts us so much, we are impelled to look at it a second time.Provokingly, we could state that this image is not the one to which Walter Benjamin refers in his famous essay ("The Work of Art in the Age of Mechanical Reproduction") that has lost its aura, but, on the contrary, the one that preserves an aura, once that for Benjamin (quoting José Gil): "The aura comes from things and beings [...]. It manifests itself in the feeling of the unapproachable and remote provided by the experience of the singular unique, of the here and now of an object. Thus, the perception of the aura as perception of the unicity of the object is apprehension of the invisible, of the concealed. The near is transparent, unveiled, looses its singularity, its image is clear and distinct, and therefore reproducible. On the contrary, the unique 'only happens once' because it has its irreplaceable place in the life and history: and the soul is this life's vibration (this time) as it offers itself to the perception. It is for this reason that Benjamin compares the perception of the aura with a 'look that rises'; because there are dead looks, empty, missing, as those of the modern man, and alive looks, auratic, veiled and vibrant because animated"1. Afterwards, José Gil, continuing to follow Benjamin's ideas, points that the perception of the aura is the "vision of the invisible (linked to the visible image in the same manner as a widely used object becomes itself 'inhabited')" and that this invisible connects itself to the unconscious and to the time (individual and historical)"2. When we look at the image a second, third or fourth time, we are thrown in the relentless pursuit of the perception of the aura of the image, trying to understand what is shown to us as visually inaccessible. It is very common to approach the image making it reveal ${ }^{3}$, unveil, the successive layers of an increasing definition until the image emerges to us as clear and nitid.

\footnotetext{
1 In Gil, José; A imagem-nua e as pequenas percepções. Lisboa: Relógio d'Água, 1996, pp. 62-63 (Translation by the author).

2 Idem.

3 In Portuguese, reveal is also used for the photographic processing of the analog negatives, which demands a proper time and space.
} 
There are authors elevating this unveiling to the utmost (whence we could ask if is not implicit, in those cases, a need for the destruction of the aura), carrying out a deep investigation into reality's realm (and we should not confuse reality with production of the real), where they verify the historical, social, political, among others, contexts of the image's production and fabrication, making several zooms out to look into what is removed from the framework, if there is any data correction, what type of correction, what type of camera is used, what lens, how much light and what type of light, what images hover over this one and which were produced before, seeking to draw a chronological line of the image, establishing a before and an after, that, in the end, are increasingly becoming imperceptible in the images, at least in those that are fiction. It seems an almost obstinacy of the authors to reach and express what is, in fact, of the order of the invisible. Even if the image belongs to the order of the visible and may be closer to the things and beings of which can be said "representation", it has no obligation to become a fact, but rather may contain grey, ambiguous and informal areas, in order to constitute itself, therefore, an auratic object, as, in the end, Benjamin denotes. The Sophia series has as its main goal to recollect this experience of the aura of the image, however, in-between words. The image becomes a presence through words, that don't describe it, but think within it, bringing to the surface the invisible and the unconscious, and, above all, our gaze returned to ourselves, to our own thought. It is, for this reason, that I try to evoke, in this small introduction, Benjamin's idea of aura, as sometimes we dedicate too much of our research to the technical data of an image, when it seems more fair to the image itself to devote it to the time and the remembrance of the aura. As Maria Filomena Molder, an attentive reader and passionate commentator of Benjamin, expresses: "The aura is an exercise of passion to a thing, of willingness to suffer the effects of the action that that thing has upon us. On the other hand, the aura concerns to not tire the eyes of seeing something or a being, that which does not cease to feed the desire" 4 .

\footnotetext{
4 In Molder, Maria Filomena; Semear na Neve. Lisboa: Relógio d'Água, 1999, p. 56 (Translation by the author).
} 